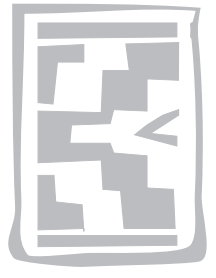

\title{
Ethnoveterinary medicine practices among Tsonga speaking people of South Africa
}

\author{
D. LUSEBA ${ }^{1}$ and D. VAN DER MERWE ${ }^{2}$
}

\begin{abstract}
LUSEBA, D. \& VAN DER MERWE, D. 2006. Ethnoveterinary medicine practices among Tsonga speaking people of South Africa. Onderstepoort Journal of Veterinary Research, 73:115-122

Rapid Rural Appraisal methods were used to collate and code the indigenous knowledge on animal healthcare of Tsonga speaking people of South Africa. There was a rapport between local disease names as described by their clinical signs by the farmers and the local veterinary services important disease list. The perceived causes of diseases were physico-biological elements and no reference to ancestral guidance was recorded. Males and old people were more knowledgeable but females and young people did show a certain degree of confidence during general discussions. Plants were more frequently used than other non-conventional remedies with cattle being the most treated animals. Farmers reported using 19 plant species belonging to 12 families. Plants were collected from the wild when needed and no specific storage system was used. They were administered as decoctions or infusions of single plants. These remedies were used not only as alternatives to expensive pharmaceutical products but also because in certain diseases or chronic cases, they were thought to be more efficacious.
\end{abstract}

Keywords: Ethnoveterinary medicine, medicinal plants, Tsonga, South Africa

\section{INTRODUCTION}

Traditional medicine is part of the indigenous knowledge systems of people all over the world. Traditional practices, used to keep their animals healthy and productive, and to treat and control diseases, constitute ethnoveterinary medicine (EVM) (MathiasMundy \& McCorkle 1989). Traditional medicine is, in many rural areas of the Republic of South Africa (RSA), sometimes the only available alternative to expensive or unavailable modern orthodox health care for the management of both human and animal health. The high cost of pharmaceutical products and

1 Agricultural Research Council, Onderstepoort Veterinary Institute, Private Bag X05, Onderstepoort, 0110, South Africa E-mail: LusebaD @ arc.agric.za

2 College of Veterinary Medicine, North Carolina State University, 4700 Hillsborough Street, Raleigh, NC, 27606, USA

Accepted for publication 13 March 2006-Editor lack of access to veterinary services are significant reasons for farmers to use non-conventional medicines. Small-scale farmers use plants extensively for the treatment of livestock diseases (Cunningham \& Zondi 1991; Masika, Sonandi \& Van Averbeke 1997a, b; Dold \& Cocks 1999, 2001; Masika, Van Averbeke \& Sonandi 2000; Van der Merwe, Swan \& Botha 2001). It is a common thread running through most traditional medicinal systems in Africa (Iwu 1994). In a previous ethnobotanic survey in this same study area, Liengme (1981) recorded 32 medicinal plant species but only two of these plants, i.e. Pterocarpus angolensis (Fabaceae) and Sarcostemma viminale (Asclepiadaceae) were reported as EVM remedies in that study. Other authors (Mashabane, Madzibane \& Potgieter 2000; Kloppers 2001) also did not report any EVM implications.

This study is part of a regional project, the Southern African Development Community (SADC) EVM pro- 
ject. It was perceived that no specific study had been done on the existence, purpose and effectiveness of indigenous veterinary remedies of the Tsonga ethnic group in South Africa. The present study was aimed at collecting, collating, validating and coding information pertaining to the practices of traditional veterinary medicine among the Tsonga people. The Tsongas are a minority ethnic group in the RSA. They are primarily rural farmers in the Limpopo Province bordering Mozambique, who grow crops and keep cattle and goats (Liengme 1981).

\section{MATERIALS AND METHODS}

\section{Study area}

The study was conducted in the Greater Giyani municipality, which forms the biggest part of the former Gazankulu homeland in the eastern part of the Limpopo Province of South Africa (Fig 1). The vegetation of the area includes two vegetation types in the savanna biome i.e. Mixed Lowveld Bushveld and Mopane Bushveld (Low \& Rebelo 1998). The area has a wet and hot summer with a mean temperature

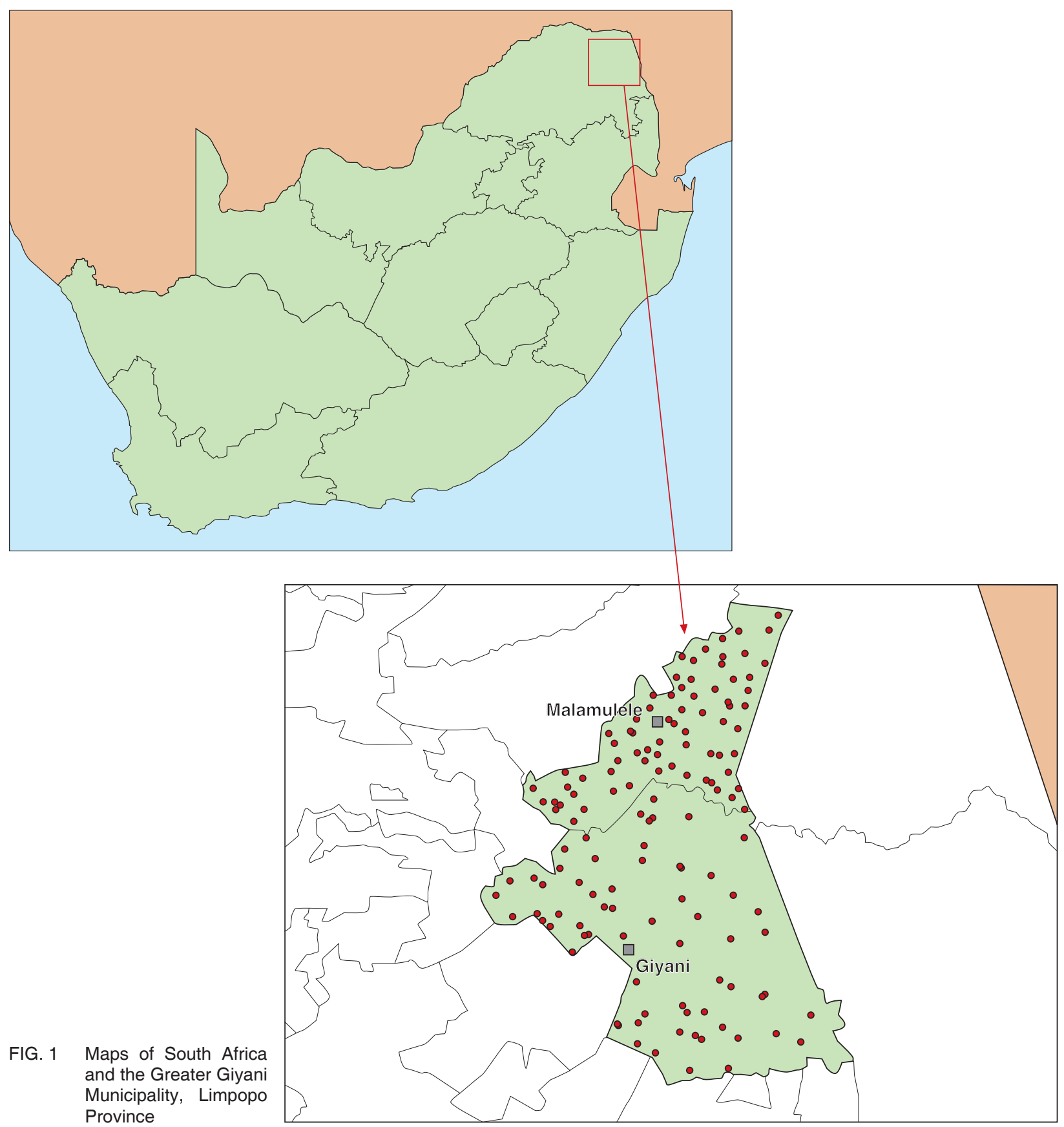


of $30^{\circ} \mathrm{C}$, and a dry and cool winter with a mean temperature of $18^{\circ} \mathrm{C}$.

\section{Methodology}

Rapid Rural Appraisal (RRA) methods were used (Beebe 1995). Meetings with the traditional leader and the state veterinary service officers were conducted at the onset to explain the purpose of the research. Oral interviews were thereafter conducted with farmers (approximately 200) between March 2002 and August 2003 at different communal dipping tanks in groups or individually. Two traditional healers were interviewed individually. The interviews were conducted through a translator who in most of the cases was one of the local veterinary technicians. A general feedback session attended by 73 people was organized in March 2004 in order to correct, harmonize and share the information among farmers. Key areas of investigation and discussions were the farmer's socio-economic profile, animal husbandry, and local knowledge in animal healthcare (ethno-aetiology, ethno-diagnostics, treatments and disease control). Detailed information on plants used was recorded including local name, indications, preparation, administration and dosage where applicable. This information was captured in an MS Access based database called OVI EVM Mobile Survey@ developed at the Onderstepoort Veterinary Institute (OVI).

\section{Plant collection}

Plants were collected under the guidance of the respondents. Botanical data were collected using a collection form prescribed by the South African National Biodiversity Institute (SANBI). Notes were also taken from discussions with respondents. Pictures of the plants were taken with a digital camera and precise coordinates of the locations were taken with a GPS instrument (eTrex GarminiTM). Three specimens of each species were collected, labelled and pressed according to the methods of Fish (1999). One specimen was sent to the SANBI for identification, and two specimens were mounted and preserved in the herbarium at OVI. Approximately $2 \mathrm{~kg}$ of fresh plant materials were collected, dried in the shade and stored in darkened glass jars for subsequent laboratory investigations.

\section{RESULTS AND DISCUSSION}

\section{Farmers' profile}

Most of the respondents (70\%) were males above the age of 40 . However, a considerable number of females and young males participated in the group discussions during interviews at the dipping tanks and the workshop. Women were generally accepted at the dipping tanks contrary to practice among other ethnical groups such as the VhaVenda (Mabogo, personal communication 2004). The farmers in Giyani and Malamulele areas keep several domestic animal species including, in decreasing order of importance, cattle, goats, chickens, sheep, dogs and donkeys. Traditional healers were generally not consulted for animal healthcare. They were rarely consulted to find lost animals or for protecting animals against witchcraft. Most of the farmers (87\%) learnt about traditional treatments from relatives and other farmers. There was very little reference to ancestral guidance as occurs in traditional human medicine. Farmers were interested in knowing the medicines used by others and they were all willing to share the information. This is contrary to traditional healers, who tend to keep their knowledge to themselves, as it is the source of their livelihood. The results of this research and our laboratory findings on the validation were keenly awaited by the respondents and other farmers.

\section{Ethnoveterinary indications}

The major disease problems in the investigated region, as reported by the state veterinary service, were high calf mortality, retained placenta, worm infection, lumpy skin disease, sweating sickness in calves, blackquarter, footrot and abscesses caused by ticks, heartwater (cowdriosis) and eye infection (C. Mabaso, personal communication 2001). Cattle were the most commonly treated, followed by goats, chickens and sheep. Van der Merwe et al. (2001) reported similar results for Tswana speaking people. There was almost no mention of treating dogs, cats and donkeys. This is probably because rural Africans do not generally keep animals as pets and because non-production animals are perceived as being more resistant than humans to different kind of ailments. Production animals are also more important because of their socio-economic importance in the African's life. This has far reaching implications on training of animal healthcare officers in the country, and service rendering to African communities needs to be focused on production animals.

\section{Perceived causes and diagnoses}

From the description of disease signs by farmers and known disease patterns, major livestock diseases could be coded (Table 1). However, it was difficult to accurately match the indigenous names of the dis- 
eases with the conventional ones as noted previously by Mathias-Mundy \& McCorkle (1989). The causes of disease and patterns were not always clearly defined but physico-biological elements were considered as major causes of diseases as demonstrated elsewhere (Van der Merwe et al. 2001).

The farmers considered drinking dirty water as a cause of redwater (bovine babesiosis). According to farmers, heartwater is suspected when an over-excited animal runs and suddenly falls dead with froth from the mouth. It was thought to be caused by excessive accumulation of blood in the head. This is why this condition was also treated traditionally by cutting a small edge of the animal's ear to let the blood flow. It was also thought that tick borne diseases such as heartwater and redwater are propagated through tick saliva. Tick bites were recognised by farmers as the biggest causes of wounds. Wounds were well defined and treated with irritant plants.

Blackquarter was suspected when the animal failed to wake up and was limping and, sometimes, showed swellings on the legs. These clinical signs were reported to occur in spring or after frost in winter.

Internal parasite infection was strongly linked to diarrhoea and lack of appetite but differentiating nematode infections from tapeworms or flukes were often non-specific and difficult to categorize.

Newcastle disease in chickens was matched with signs of greenish diarrhoea and paralysis occurring when seasons change. There was no mention of supernatural causes of animal diseases and no rituals were observed when diagnosing or treating livestock.

TABLE 1 List of Tsonga important animal disease names and corresponding conventional names

\begin{tabular}{|l|l|}
\hline Local name & Conventional name \\
\hline Xihlakahla/ Nyongwa & Gallsickness (anaplasmosis) \\
Shimeme & Heartwater \\
Foloja & Abortion \\
Jenejene & Newcastle disease (NCD) \\
Dzohana & Blackquarter \\
Matsumba & Wounds, Lumpy skin disease \\
Mbuphye & Warts \\
Gugumagala & Bottle jaw \\
\hline
\end{tabular}

\section{Plant use and veterinary consistency}

Plants were predominantly used in the treatment of livestock diseases compared to other traditional remedies (Table 2). Data on plant usage were analysed according to the criteria of veterinary consistency as defined by Kansonia \& Ansay (1997). There is consistency when the same plant genus or family is mentioned at least twice for treating the same illness. Nineteen species belonging to 12 plant families were reported, the most common families being Euphorbiaceae and Fabaceae with four plants each. Plants mentioned by traditional healers (Balanites maughamii (Balanitaceae), Combretum paniculatum (Combretaceae), Diospyros mespiliformis (Ebeneceae), Dombeya rotundifolia (Sterculiaceae), and Elephantorrhiza elephantina (Fabaceae) were unknown to farmers individually, but they were able to identify the plants from digital pictures during the feedback session.

Plants were not processed or mixed with other materials in most cases. They were used as single plant decoctions or infusions for dosing animals or crushed and used topically for wound treatment. This is in contrast to traditional healers who frequently use complex mixtures. This agrees with findings in Madikwe, Northwest Province (Van der Merwe et al. 2001) but contradicts those of Masika et al. (2000) in the Eastern Cape Province. Farmers gave many reasons why ethnoveterinary medicines are still in use including the claim of the absence of side effects or being more efficacious than pharmaceuticals. The farmers also indicated that traditional medicines are preferred because there are no restrictions or withdrawal periods for consumption of meat from treated animals. In general, traditional medicines were used as second choice after pharmaceutical medicines, for chronic cases and when pharmaceutical medicines were ineffective.

Tsonga people make lesser use of phytotherapy as shown by the shorter list of 19 plants recorded in this study when compared to that of other ethnic groups i.e. Zulu who use more than 40 species (Cunningham \& Zondi 1991), the Xhosa who use 53 species (Dold $\&$ Cocks 2001) and the Batswana who use approximately 50 species (Van der Merwe et al. 2001). Ethnically, Tsongas are a minority group in South Africa and it is assumed that loss of tradition in a minority group is greater than in bigger groups. Young people are not keen to use EVM, probably due to lack of information and interest or to rural exodus as suggested by Van der Merwe et al. (2001). Furthermore, the study area is a buffer zone for the Kruger National Park. It is a national policy to effectively prevent the transfer of controlled diseases, such as foot-and-mouth disease, from certain game carrier species to livestock. For many decades, dipping to control ticks and other veterinary services 
have been provided free of charge which have contributed to lesser use of ethnoveterinary medicines.

The availability of a plant per se does not seem to influence its uses more than traditional and sociocultural characteristics and inheritance. Some common plants occurring in the region (Liengme 1981) that were frequently used by many other ethnic groups were not reported. To name a few of these, plants such as Acacia tortilis (Fabaceae), Albizia versicolor (Fabaceae), Brachylaena discolor (Asteraceae), Combretum erythrophylum (Combretaceae), Dicrostachys cinerea (Fabaceae), Grewia occidentalis (Tiliaceae), Leonotis spp. (Lamiaceae), Lippia javanica (Verbenaceae), Ozoroa reticulata (Anacardiaceae), Sclerocarya birrhea (Pedaliaceae) and Ziziphus mucronata (Rhamnaceae) were not reported.

There were three similar usages of EVM plants among Tsongas and other ethnic groups. Dicerocaryum eriocarpum (Pedaliaceae) is used by both Tsongas and Batswana (Van der Merwe et al. 2001) for dystocia and retained placenta. Aloe zebrina (Asphodelaceae) is used for wounds or burns and $E$. elephantina for heartwater. More plants were used in common with VhaVenda who are living in a much closer region (OVI EVM Mobile Survey@), unpublished data, 2003). These are Aloe marlothi, Cassia abbreviata (Fabaceae), Cissus quandrangularis (Vitaceae), D. eriocarpum, D. rotundifolia, E. elephantina, Jatropha curcas (Euphorbiaceae), P. angolensis, S. viminale, Senna italica (Fabaceae), Solanum lichtensteinii (Solanaceae), Synadenium cupulare (Euphorbiaceae) and Terminalia sericea (Combretacae).

\section{Mode of action, preparation and storage}

The mode of action of plants was not always well explained by farmers. In case of general illness, a plant supposedly stimulates blood circulation and would act as a cleansing factor. The doctrine of signature (i.e. plant that produces a red decoction is given for a disease that in its signalment shows red, such as haemoglobinuria with babesiosis) was also present. For instance, $D$. eriocarpum is used both topically as a lubricant during dystocia and per os in the treatment of retained placenta because of the soapy character of the infusion. Water was exclusively used as a solvent, but there was no precise amount of plant material per volume of water. Qualitative estimates such as colour change (red colour for $P$. angolensis and E. elephantina) of the liquid after a certain period when plant material is soaked or the formation of a slippery infusion $(D$. eriocarpum) are used to determine adequate concentration of preparations. It is, therefore, difficult to standardize such remedies and make objective recommendations. However, a $1 \ell$ bottleful and a big horn are often used for dosing adult cattle, while amounts of a quarter to a half bottleful are used for calves.

Plants were collected when needed in the wild but medicines that were perceived to be essential, such as roots of Jatropha zeyheri (Euphorbiaceae) and ground bark of $P$. angolensis, were often stored. Farmers were aware that medicinal plants are getting scarce and would indiscriminately use fresh materials from nurseries - contrary to general practice in human traditional medicine (Van der Merwe et al. 2001). They also indicated that fresh material was more effective than dried material. Traditional healers store large numbers of medicinal plants and recommend that plant materials be ground and stored in preferably dark bottles. They acknowledged that ground plant material might lose efficacy after a year. Bundled, intact medicinal plants were stored in shade for longer periods. Some medicines were stored in a refrigerator, but were not allowed to freeze.

TABLE 2 List of plant family and botanical names followed by Tsonga names, plant part (s) used, indication(s), preparation and dosage where applicable

\begin{tabular}{|l|l|l|l|l|}
\hline $\begin{array}{l}\text { Family and } \\
\text { botanical name }\end{array}$ & Tsonga name & Indication & Plant part & Preparation \\
\hline $\begin{array}{l}\text { Asclepiadaceae } \\
\text { Sarcostemma viminale }\end{array}$ & Neta & Wound & Aerial part & $\begin{array}{l}\text { Grind and apply directly on the wound. Very } \\
\text { effective against maggots }\end{array}$ \\
\hline $\begin{array}{l}\text { Asphodelaceae } \\
\text { Aloe marlothii }\end{array}$ & Mhangani & $\begin{array}{l}\text { Newcastle } \\
\text { disease(NCD) }\end{array}$ & Leaves & $\begin{array}{l}\text { Leaves are crushed and the juice is mixed } \\
\text { with drinking water for treating chickens } \\
\text { against NCD. It is also planted in the yard to } \\
\text { protect the household against lightning } \\
\text { strike }\end{array}$ \\
\hline $\begin{array}{l}\text { Asphodelaceae } \\
\text { Aloe zebrinae }\end{array}$ & Chovoloti & Wound & Leaves & $\begin{array}{l}\text { Succulent fresh leaves are crushed and } \\
\text { applied on wound; it is good against } \\
\text { maggots }\end{array}$ \\
\hline
\end{tabular}


TABLE 2 (Continues)

\begin{tabular}{|c|c|c|c|c|}
\hline $\begin{array}{l}\text { Family and } \\
\text { botanical name }\end{array}$ & Tsonga name & Indication & Plant part & Preparation \\
\hline $\begin{array}{l}\text { Balanitaceae } \\
\text { Balanites maughamaii }\end{array}$ & Nulu & Diarrhoea & Leaves & $\begin{array}{l}\text { Grind the leaves and mix with cold water. } \\
\text { Dose with } 1 \ell \text { bottle for adults and a } 340 \text { m } \ell \\
\text { bottle for calves. After treatment, animals } \\
\text { are housed only after they have eaten }\end{array}$ \\
\hline $\begin{array}{l}\text { Combretaceae } \\
\text { Combretum paniculatum }\end{array}$ & Mpfunta & $\begin{array}{l}\text { For fertility } \\
\text { problems }\end{array}$ & Root bark & $\begin{array}{l}\text { Grind root bark, make a decoction, sieve, } \\
\text { dose approximately } 500 \text { m } \ell \text {. Use only when } \\
\text { animal is not fertile, give twice at } 2 \text { days, } \\
\text { interval }\end{array}$ \\
\hline $\begin{array}{l}\text { Combretaceae } \\
\text { Terminalia sericea }\end{array}$ & Konono & Wound & Leaves & $\begin{array}{l}\text { Grind leaves, mix with water and apply on } \\
\text { the wound; cover with cattle dung }\end{array}$ \\
\hline $\begin{array}{l}\text { Ebeneceae } \\
\text { Diospyros mespiliformis }\end{array}$ & Ntoma & $\begin{array}{l}\text { For milk } \\
\text { production }\end{array}$ & Bark & $\begin{array}{l}\text { Grind bark and mix with hippopotamus fat; } \\
\text { dose and also rub into vagina }\end{array}$ \\
\hline $\begin{array}{l}\text { Euphorbiaceae } \\
\text { Euphorbia cooperi }\end{array}$ & Mokhoto/Nkonde & Blackquarter & Aerial part & $\begin{array}{l}\text { Crush succulent stems, mix with water and } \\
\text { drench the animal. It is also planted in the } \\
\text { yard to prevent lightning strike }\end{array}$ \\
\hline $\begin{array}{l}\text { Euphorbiaceae } \\
\text { Jatropha curcas }\end{array}$ & Nhlampfura & Constipation & Seeds & $\begin{array}{l}\text { Crush one or two seeds, mix with water and } \\
\text { drench the animal for treatment of } \\
\text { constipation in cattle and goats }\end{array}$ \\
\hline $\begin{array}{l}\text { Euphorbiaceae } \\
\text { Jatropha zeyheri }\end{array}$ & $\begin{array}{l}\text { Xidomeja/ } \\
\text { Mudomeja }\end{array}$ & $\begin{array}{l}\text { General } \\
\text { ailments, ill- } \\
\text { thrift, and } \\
\text { diarrhoea }\end{array}$ & Roots & $\begin{array}{l}\text { Together with } P \text {. angolensis, they are the } \\
\text { most used plants. Fresh or dry roots are } \\
\text { ground, soaked in water and dosed to } \\
\text { animals for all sorts of ailments, unthrifti- } \\
\text { ness, and diarrhoea }\end{array}$ \\
\hline $\begin{array}{l}\text { Euphorbiaceae } \\
\text { Synadenium cupulare }\end{array}$ & Mdleve & $\begin{array}{l}\text { Eye infection, } \\
\text { blackquarter }\end{array}$ & Milky latex & $\begin{array}{l}\text { Apply milky latex on the third eyelid for eye } \\
\text { infections or on the skin of the limping leg } \\
\text { for treatment of blackquarter. Protect the } \\
\text { eye since the latex can damage it }\end{array}$ \\
\hline $\begin{array}{l}\text { Fabaceae } \\
\text { Cassia abbreviata }\end{array}$ & Lumanyama & $\begin{array}{l}\text { Worm } \\
\text { infestation }\end{array}$ & Bark & $\begin{array}{l}\text { Grind the bark, soak in water overnight or } \\
\text { boil, cool, sieve and drench the animals }\end{array}$ \\
\hline $\begin{array}{l}\text { Fabaceae } \\
\text { Elephantorrhiza } \\
\text { elephantina }\end{array}$ & Xixuvari & $\begin{array}{l}\text { Heartwater, } \\
\text { black- quarter } \\
\text { and as appetite } \\
\text { stimulant or } \\
\text { tonic }\end{array}$ & $\begin{array}{l}\text { Aerial parts } \\
\text { and bulb }\end{array}$ & $\begin{array}{l}\text { Grind and soak plant material in cold water } \\
\text { for } 6 \mathrm{~h} \text {. When the water becomes reddish, } \\
\text { dose } 1 \ell \text {; give every morning until the } \\
\text { animal recovers }\end{array}$ \\
\hline $\begin{array}{l}\text { Fabaceae } \\
\text { Pterocarpus angolensis }\end{array}$ & $\begin{array}{l}\text { Vhangazi/ } \\
\text { Murhotso }\end{array}$ & $\begin{array}{l}\text { General illness, } \\
\text { unthriftiness, } \\
\text { gallsickness, } \\
\text { intestinal } \\
\text { worms, } \\
\text { blackquarter }\end{array}$ & Bark & $\begin{array}{l}\text { Chop the bark, soak in cold water, dose } \\
\text { once only with bottle or horn (approximately } \\
750 \mathrm{~m} \ell \text { ) after the water has changed to } \\
\text { reddish or boil for } 30-60 \text { min. To prevent } \\
\text { "blood diseases" (blackquarter/anthrax?), } \\
\text { the potion is given twice annually, when the } \\
\text { seasons change }\end{array}$ \\
\hline $\begin{array}{l}\text { Fabaceae } \\
\text { Senna italica }\end{array}$ & $\begin{array}{l}\text { Ximbangam- } \\
\text { bangana }\end{array}$ & $\begin{array}{l}\text { Diarrhoea and } \\
\text { gallsickness }\end{array}$ & Bark & $\begin{array}{l}\text { Grind the bark, soak in water and dose } \\
\text { cattle for diarrhoea and gallsickness }\end{array}$ \\
\hline $\begin{array}{l}\text { Pedaliaceae } \\
\text { Dicerocaryum } \\
\text { eriocarpum }\end{array}$ & Dinda/Dindza & $\begin{array}{l}\text { Dystocia, } \\
\text { retained } \\
\text { placenta }\end{array}$ & Aerial part & $\begin{array}{l}\text { Crush the aerial parts and mix with water. It } \\
\text { is used as lubricant during difficult calving } \\
\text { and drenched }(5 \ell) \text { for retained placenta }\end{array}$ \\
\hline $\begin{array}{l}\text { Solanaceae } \\
\text { Solanum lichtensteinii }\end{array}$ & Ndhulwani & $\begin{array}{l}\text { Respiratory } \\
\text { problems }\end{array}$ & Aerial part & $\begin{array}{l}\text { Crush aerial part and mix with water, instill } \\
\text { the fluid in the nostril to clear up the airways } \\
\text { in case of upper respiratory problems }\end{array}$ \\
\hline
\end{tabular}


TABLE 2 (Continues)

\begin{tabular}{|l|l|l|l|l|}
\hline $\begin{array}{l}\text { Family and } \\
\text { botanical name }\end{array}$ & Tsonga name & Indication & Plant part & Preparation \\
\hline $\begin{array}{l}\text { Sterculiaceae } \\
\text { Dombeya rotundifolia }\end{array}$ & Shilubare/xiluvarhi & $\begin{array}{l}\text { Newcastle } \\
\text { disease }\end{array}$ & $\begin{array}{l}\text { Leaves and } \\
\text { flowers }\end{array}$ & $\begin{array}{l}\text { Grind leaves/flowers and mix with chicken } \\
\text { feed during the outbreaks. It is used } \\
\text { generally when seasons change to prevent } \\
\text { the disease }\end{array}$ \\
\hline $\begin{array}{l}\text { Vitaceae } \\
\text { Cissus quandrangularis }\end{array}$ & Nyangala & $\begin{array}{l}\text { Wound } \\
\text { treatment, tick } \\
\text { repellent, lumpy } \\
\text { skin disease }\end{array}$ & Aerial parts & $\begin{array}{l}\text { Crush aerial parts, mix with water and use } \\
\text { as poultice. It is used to control maggots } \\
\text { and ticks. Can be used to prevent second- } \\
\text { ary wound infection due to tick bites. In } \\
\text { case of lumpy skin disease, crush the stem, } \\
\text { mix with water, red soil (tsumani), and pork } \\
\text { fat; smear the whole body }\end{array}$ \\
\hline
\end{tabular}

\section{Other EVM remedies}

Other indications included the treatment of gallsickness with an infusion of a portion of ground abomasum of a kudu (Tragelaphus strepsiceros). Hippopotamus fat was smeared onto the vulva of cows to attract bulls in cases of female infertility. A pinch of powder of ground shell from the large terrestrial snails named wumba, the Tsonga name for Achatina spp., was applied to the eyeball, usually two times every second day for treating chronic eye infections. Mixtures of clay and water or salt and water were used for treating intestinal conditions like diarrhoea. A mixture of salt, potassium permanganate and Coca Cola ${ }^{\mathrm{TM}}$ was used for the same condition.

\section{CONCLUSION}

The Tsonga people of South Africa practice EVM, although to a lesser extent than the VhaVenda, Batswana and Xhosa. However, there are some similar usages of medicinal plants showing a consistency across ethnic groups in the country. Women and young people do have a knowledge of EVM, and it seems that they participate and learn during open discussions. Organizing surveys and workshops during school holidays and when women are not involved in other activities can encourage this. It was also shown that organizing a feedback session at the end of the research period was important. Not only was it possible to have a consensus on the results, but farmers also learnt from others. It was also an opportunity to make recommendations such as the appropriate use of medicinal materials, harvesting methods and methods for growing medicinal plants.

There is evidence to suggest that farmers have a unique knowledge of disease causes and patterns
(Masika et al. 1997a), which is not always comparable to scholastic understanding. However, it is often related to the type of treatment used. This should be taken into account in any disease control campaign since people relate easily to what is already embedded in their traditions. It was also shown that production animals are important in rural communities and efforts to improve animal productivity through effective health management are of utmost importance.

Further studies to explain the rationale behind the use of these remedies should be conducted based on biological and chemical analyses. These should form the bases of recommendations made to communities.

\section{ACKNOWLEDGEMENTS}

The authors are grateful for funding from the Department of Science and Technology, South Africa and Dr Jenny Turton for obtaining funding. The co-operation and patience of the communities, especially Chief Ngobe, Mr M. Mabunda and the state veterinary services of Greater Giyani, Limpopo Province, South Africa are gratefully acknowledged. Dr C. Mabaso is thanked for chairing and helping in the general organization of the feedback session with the communities.

\section{REFERENCES}

BEEBE, J. 1995. Basic concepts and techniques of rapid appraisal. Human organization, 54:42-51.

CUNNINGHAM, A.B. \& ZONDI, A.S. 1991. Cattle owners and traditional medicines used for livestock. Institute of Natural Resources, University of Natal, Pietermaritzburg (Investigational Report, no. 69). 
DOLD, A.P. \& COCKS, M.L. 1999. Preliminary list of Xhosa plant names from the Eastern Cape Province, South Africa. Bothalia, 29:267-292.

DOLD, A.P. \& COCKS, M.L. 2001. Traditional veterinary medicine in the Alice district of the Eastern Cape Province, South Africa. South African Journal of Science, 97:375-379.

FISH, L. 1999. Preparing herbarium specimens. Pretoria: National Botanical Institute.

IWU, M.M. 1994. African medicinal plants in the search for new drugs based on ethnobotanical leads, in Ethnobotany and the search for new drugs. Chichester: Wiley.

KANSONIA, K. \& ANSAY, M. 1997. A recognition of rural knowledge: medicinal plants and traditional veterinary medicine of central Africa (testing the traditional veterinary pharmacopoeia), in Ethnoveterinary medicine: alternatives for livestock development, Proceedings of an International Conference held in Pune, India: 14-18.

KLOPPERS, R.J. 2001. A comparison of plants utilised by Tsonga people in South Africa and Mozambique. Southern African Ethnobotany: The official Newsletter of the Indigenous Plant Use Forum, 1:32-41.

LIENGME, C.A. 1981. Plants used by the Tsonga people of Gazankulu. Bothalia, 13:501-518.

LOW, A.B. \& REBELO, A.G. 1998. Vegetation of South Africa, Lesotho and Swaziland, $2^{\text {nd }}$ ed. Pretoria: Department of Environmental Affairs and Tourism.
MASHABANE, L.G., MADZIBANE, J. \& POTGIETER, M.J. 2000. A comparative analysis of mopane's uses between the VaTsonga and VhaVenda. Southern African Ethnobotany: The official Newsletter of the Indigenous Plant Use Forum, 1:11-12.

MASIKA, P.J., SONANDI, A. \& VAN AVERBEKE, W. 1997a. Perceived causes, diagnosis and treatment of babesiosis and anaplasmosis in cattle by livestock farmers in communal areas of the central Eastern Cape Province, South Africa. Journal of South African Veterinary Association, 68:40-44.

MASIKA, P.J., SONANDI, A. \& VAN AVERBEKE, W. 1997b. Tick control by small-scale farmers in the central Eastern Cape Province South Africa. Journal of South African Veterinary Association, 68:45-48.

MASIKA, P.J., VAN AVERBEKE, W. \& SONANDI, A. 2000. Use of herbal remedies by small-scale farmers to treat livestock diseases in central Eastern Cape Province; South Africa. Journal of South African Veterinary Association, 71: 81-91.

MATHIAS-MUNDY, E. \& MCCORKLE, C.M. 1989. Ethnoveterinary Medicine: An Annotated Bibliography. Center for Indigenous Knowledge and Agricultural and Rural Development (CIKARD). Ames: lowa State University (Bibliographies in Technology and Social Change, no. 6).

VAN DER MERWE, D., SWAN, G.E. \& BOTHA, C.J. 2001. Use of ethnoveterinary medicinal plants in cattle by Setswanaspeaking people in the Madikwe area of the North West Province of South Africa. Journal of South African Veterinary Association, 72:189-196. 